\title{
Who supports secession? The determinants of secessionist attitudes among Turkey's Kurds
}

\author{
ZEKI SARIGIL* and EKREM KARAKOC** \\ * Department of Political Science, Bilkent University, Ankara, Turkey \\ **Department of Political Science, Binghamton University SUNY, \\ Binghamton, NY, USA
}

\begin{abstract}
Who supports secession in a multiethnic country? What factors lead to secessionist or separatist attitudes? Despite the substantial interest in secessionist movements, the micro-level factors and dynamics behind mass support for secession have been understudied. Using original and comprehensive data derived from two public opinion surveys, conducted in 2011 and 2013 with nationwide, representative samples, this study investigates the determinants of separatist attitudes among Turkey's Kurds. The empirical results show that perceptions of discrimination, ideological factors (i.e. a left-right division and partisanship), region and religious sect do affect support for secession. Our findings provide strong support for the grievance theory and, further, show that ideology is an important factor. However, the results call into question arguments drawing attention to the role of modernisation (i.e. socio-economic status) and of religiosity. The study also discusses some practical implications of the empirical findings.
\end{abstract}

KEYWORDS: autonomy, grievance theory, Kurdish issue, public opinion, religiosity, secession $^{1}$

\section{Introduction}

Separatist or secessionist movements are prevalent in various parts of the world (e.g. see Emizet and Hesli 1995; Hale 2000; Horowitz 1985; Richez and Bodet 2012; Rudolph and Thompson 1985; Sorens 2004, 2005; Treisman 1997; Williams 1982) and are one of the challenges to the international system of states. The existing literature provides several empirical studies, investigating the various aspects of secessionist movements, such as civil war onset, rebel recruitment, and the strength and success of separatist groups in their struggle

\section{Funding}

The data that this article uses come from two public opinion surveys conducted in 2011 and 2013 and fully funded by TEPAV (Economic Policy Research Foundation of Turkey). 
against central governments (e.g. see for instance Fearon and Laitin 2003; Gurr and Moore 1997; Hale 2000; Heraclides 1990; Richez and Bodet 2012; Sorens 2005; Treisman 1997). However, few empirical studies examine the factors and dynamics behind separatist beliefs and attitudes among individual members of an ethnic minority (see Cuneo and Curtis 1974; Hagendoorn et al. 2008; Saideman and Ayres 2000). Focusing on popular support for secession, this study is interested in the following questions: Who supports secession in a multiethnic country? Why do the members of an ethnic group want to withdraw their loyalties and political activities from the jurisdiction of the existing state? What factors drive secessionist or separatist attitudes and beliefs?

We believe that Kurdish separatism constitutes an excellent case for studying popular support for secession because Kurds, who inhabit a land divided among Turkey, Iraq, Iran and Syria, are one of the largest ethnic communities in the world without an independent state of their own (Gottlieb 1994; Gunter 2004). ${ }^{1}$ It is thus worthwhile to analyse to what extent and why Kurds support secession from their current state. It would be ideal to examine secessionist tendencies among Kurds in all those countries. However, due to practical reasons (i.e. availability of data), we focus on Turkey's Kurds in this study. To the best of our knowledge, this study is one of the few quantitative analyses of mass support for 'secessionism' and probably the first one focusing on Kurdish 'separatism' in Turkey.

Although Kurdish ethnonationalism has been one of the main challenges faced by the Turkish state in the last decades, there is little empirical knowledge of Kurdish separatism. Thus, in November 2011, one of the authors participated in a research team that conducted a nationwide survey to analyse Kurdish attitudes towards secession in Turkey. In 2013, right after the launch of peace negotiations between the leadership of the outlawed ethnonationalist Kurdistan Workers' Party (Partiya Karkaren Kurdistan [PKK]) and the Turkish government, the same survey (with some additional questions) was conducted to determine whether there had been a significant change in Kurds' attitudes towards secession. As explained later, unlike many other civil war contexts, the ceasefire between the PKK and the security forces and Turkey's relatively more open political environment at that time (see below) provided opportune conditions for conducting the two surveys for this research project. ${ }^{2}$

According to the official Turkish state discourse, Kurds residing in Turkey are not demanding secession. It is believed that 'the separatist and terrorist' PKK does not enjoy widespread public support in the region. It is further claimed that 'separatist terror' by the PKK is due to feudalism and socioeconomic backwardness in the region and foreign incitement (Lundgren 2007: 57-72). However, contrary to this official discourse, our descriptive analyses show the presence of strong separatist attitudes among Turkey's Kurds. As Figure 1 shows, in 2011, fifty-five per cent of Kurdish respondents supported autonomy, while twenty-three per cent demanded total separation. ${ }^{3}$ And these figures are on the rise. The results of our second survey, conducted in April 2013 in the aftermath of the start of the peace negotiations with the PKK 


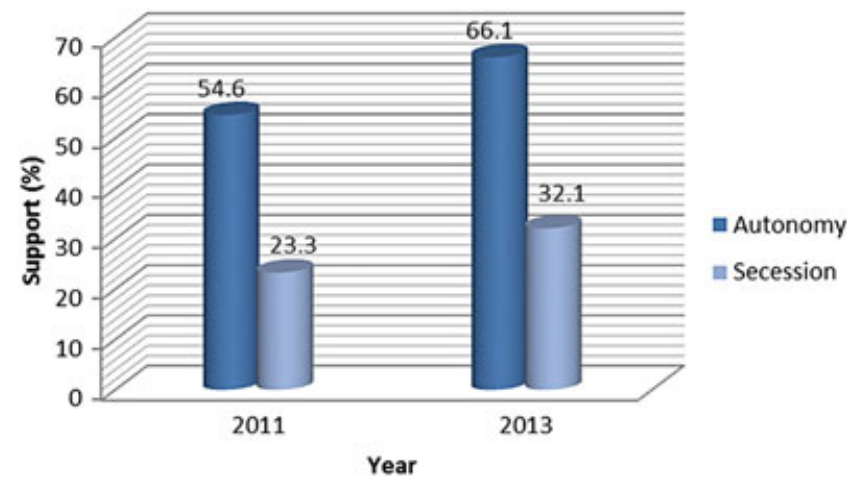

Figure 1. Kurdish support for autonomy and secession (2011-2013).

leadership, show that sixty-six per cent of Kurdish respondents demand autonomy, while thirty-two per cent want separation. These figures also indicate that Kurdish support for autonomy has been relatively higher. This is probably because since the early 2000s, Kurdish ethnopolitical elites have been denouncing secession. Instead, they demand a kind of regional autonomy, labelled by the Kurdish movement either as 'democratic confederalism' or 'democratic autonomy'. Nevertheless, almost one-third of Turkey's Kurds still express support for Kurdish independence. Why?

We derive hypotheses from two main approaches in the conflict literature, and then test them using original data from our two surveys. These approaches explore the role of grievance and religiosity in ethnonationalist processes. Our empirical analyses, based on comprehensive survey data, partly support the grievance approach and question the assumptions of the religiosity perspectives. Notably, we also find that partisanship (i.e. support for the pro-Kurdish Peace and Democracy Party, Barlş ve Demokrasi Partisi [BDP] $)^{4}$ and leftist ideological tendencies increase the likelihood of secessionist attitudes, suggesting that political and ideological factors and variables also matter in Kurdish secessionism.

The article proceeds as follows: The next section provides a brief discussion of the grievance and religiosity approaches and draws some testable hypotheses on popular support for secession. The empirical section first presents the data, variables and measurement and then provides statistical results. The final section summarises the results of the empirical analyses and discusses further theoretical and practical implications of the findings.

\section{Hypotheses}

\section{Grievance approach}

The grievance approach is based on the notion of 'relative deprivation', which refers to the experience of being deprived of something that one believes 
oneself to be entitled to or qualified for. As Walker, Wong and Kretzschmar state:

The core of the relative deprivation (RD) construct is that when people's expectations about the goods and conditions of life to which they believe they are entitled are thwarted, they become angry and are motivated to redress the perceived inequity. Judgments about entitlements can only be made relatively - people compare their current or anticipated outcomes with those of other individuals or groups. (Walker et al. 2002: 288)

Relative deprivation theory, then, suggests that as the perceived discrepancy between 'ought' and 'is' increases, the intensity of discontent also increases. Discontent, frustration or grievance caused by unjust deprivation or differential treatment, in return, increase the likelihood of ethnic mobilisation in various forms (Gurr 1970; Gurr et al. 1993). Gurr et al. (1993: 174) asserts that 'the greater a group's relative disadvantage [e.g. political and economic differentials, poverty, discriminatory treatment] ... the greater the sense of grievance and, consequently, the greater its potential for political mobilization'.

Discrimination, which is defined as 'the extent of socially derived inequalities in group members' material wellbeing or political access in comparison with other social groups' (Gurr and Harff 1994: 83), constitutes one source of grievance and frustration. The causal logic runs as follows: discrimination, neglect, injustice, exploitation or repression in economic, political, cultural, linguistic and religious terms are expected to generate discontent, grievance, resentment, and frustration among the members of an ethnic group. As Gurr and Harff note '[o]n the most basic level, people resent and react against discriminatory treatment' (Gurr and Harff 1994). Such feelings provide a motivating force or legitimation for ethnic mobilisation, which might also appear in the form of secessionism. Regan and Norton (2005) and Walter (2006) also find a strong relationship between political discrimination and rebellions and secessionist civil wars. Thus, the grievance hypothesis postulates that political, economic and socio-cultural discrimination or disadvantages faced by an ethnic group are likely to incite separatist tendencies among the members of that ethnic group.

This approach is relevant to the Kurdish case. Turkey's security-oriented policies towards its southeastern region, traditionally inhabited by Kurds and mostly rural, further promoted the region's existing socio-economic underdevelopment. According to official figures from the Turkish Institute of Statistics (TUIK), the southeast has consistently been Turkey's least-developed region (see also Brown 1995; Gunter 2004; Icduygu et al. 1999: 1002-1006; Kibris 2011; Kirisci and Winrow 1997; Mutlu 2001; Sarigil 2012; White 1998). Further, unemployment and poverty rates are significantly higher among Kurds in general (Icduygu et al. 1999). Our descriptive analyses based on our survey data also confirm that compared to Turks, average levels of income and education are relatively lower among Kurds. 
Kurds have also faced political repression. Until the early 2000s, the state suppressed any public expression of Kurdish identity, for example, banning speaking, publishing and broadcasting in Kurdish and shutting down proKurdish political parties (Aktürk 2011). The state also crossed the line from suppression to repression, engaging in extra-judicial killings of many hundreds of Kurdish activists in the 1990s and forced village evacuations. ${ }^{5}$ As Tezcür (2009: 3) observes 'Turkish state policies toward the Kurdish speaking people involved institutional coercion, policed repression, violent repression and unpremeditated mass killings'. ${ }^{6}$ Probably because of the above-noted factors, perceptions of discrimination are extensive among Turkey's Kurds. The results of our 2013 survey, for instance, show that more than half of Kurdish respondents (fifty-four per cent) think that the Turkish state discriminates against Kurds, and around sixty per cent of Kurdish respondents believe that Kurds in Turkey are not equal with Turks in terms of enjoyed rights and freedoms and socio-economic status. ${ }^{7}$

One might argue that frustration or discontent with the state's restrictions on Kurdish cultural and political rights and the socio-economic disadvantages, which have followed, has promoted ethnic and political awareness among Kurds (e.g. see Tezcür 2010: 778). As the grievance approach also asserts, this situation is rather conducive to the rise of ethnonationalist tendencies. Thus, if the grievance hypothesis is correct, one might expect that Kurds who perceive discrimination should be more likely to support autonomy or separation. We test the following hypothesis:

\section{$H_{1 a}:$ Members of an ethnic group who have a perception of discrimination by the central state would be more likely to have separatist attitudes.}

Another source of grievance might be the differences in socio-economic or class status. The modernisation approach, for instance, draws attention to the role of socio-economic factors and variables in ethnic separatism, linking ethnic nationalism and separatism to socio-economic underdevelopment or backwardness. Horowitz, for instance, states that 'rich regions are not the leading secessionists. They are far outnumbered by regions poor in resources and productivity' (Horowitz 1981: 170, see also Gellner 1983; Hechter 1975; Horowitz 1985). It is expected, then, that modernisation (e.g. socio-economic development, upward social mobility) is likely to reduce ethnic nationalism and separatism because it is believed that higher levels of education and income would weaken primordial ethnic identifications and loyalties.

The existing empirical literature, however, provides mixed evidence for the impact of socio-economic status on popular support for secession. In terms of the supporting evidence, survey research in countries such as Northern Ireland and South Africa indicates that the most support for separatist groups comes from people with low income and education. For instance, the Irish Republican Army (IRA) in Northern Ireland was more likely to recruit volunteers among low-income groups, including the working class and unemployed (Hayes and McAllister 2001; O'Gara 2001). In 1970s Quebec in Canada, 
farmers and unskilled workers were more likely to support separatism than the professional or other middle and upper classes (Cuneo and Curtis 1974).

Several analysts, however, question the modernisation approach. For instance, it is argued that 'there are many instances of economically worse-off people who do not attempt secession, as well as some cases of better-off people who do (Croatians, Ibos, Basques)' (Wood 1981: 116). Similarly, Gurr et al. (1993: 82) states that 'Spanish Basques, Quebecois, Armenians, Ukranians, and Slovenes all were separatist in the 1980s despite regional prosperity, limited autonomy, and significant national political influence'. ${ }^{8}$ Other studies even identify a strong positive relationship between socio-economic development and separation. Hale (2000) and Hagendoorn et al. (2008) conclude that economic wealth and development are likely to promote separatism rather than suppress it. In the Russian context, Hale (2000: 44-5) shows that it is the richest, rather than the poorest, ethnic regions that are more willing to secede. To quote him, 'wealthy ethnic regions have more to fear and less to gain from remaining in a union state than do poor regions'.

The modernisation approach, nevertheless, has dominated the Turkish state's approach to the Kurdish problem. Until the 2000s, the Turkish state simply ignored the issue's ethnonationalist aspect and treated it as a problem of socio-economic backwardness (i.e. rooted in feudalism, ignorance, poverty) and of terrorism and banditry (see also Cornell 2001; Ergil 2000; Loizides 2010; Lundgren 2007; Yeğen 1996, 2007). For instance, former Prime Minister Bülent Ecevit (1925-2006) stated in 2005 that 'Turkey does not have a Kurdish problem. There is a socio-economic underdevelopment in the region. By abusing this, several external factors such as neighbouring and some European countries have promoted Kurdish terrorism/separatism in the region to destabilize and divide the Turkish Republic' (quoted in Sarigil 2010: 538).

Since Kurdish separatism is linked to socio-economic backwardness in the official state understanding, many state and government officials have expected that improving social and economic conditions in the region would reduce or suppress ethnonationalist or separatist beliefs and attitudes among the Kurds. As a result, Turkish governments have initiated several economic packages and projects to invest in and allocate resources to the region (Brown 1995; Lundgren 2007: 67-8; Mutlu 2001; Yeğen 2011: 71). Do socio-economic factors really explain Kurds' support for secession? We test the following hypothesis:

$H_{1 b}$ : Individuals with high socio-economic status (i.e. a high level of income and education) should be less likely to support autonomy or separation.

\section{Religiosity approach}

The literature contains divergent views about the effect of religion on the onset and duration of civil war in general and on secession in particular (e.g. see Collier et al. 2004; Fox 2004; Reynal-Querol 2002; Roeder 2003; Rummel 
1997; Walter 1997). With respect to religiosity, Hayes and McAllister show that church attendance reduces support for paramilitary violence in Northern Ireland (Hayes and McAllister 2001). Similarly, Zaidise et al. (2007) argue that religious people in Israel (Muslims or Jews) are less likely to support political violence but that socio-economic deprivation reverses that trend.

The religiosity perspective is also discussed frequently in debates about the Kurdish issue. The pro-Islamic approach (also known as Islamic peace approach) attributes primary importance to overarching ideas and identities such as the 'Islamic brotherhood' and 'ummah' (the worldwide community of Muslim believers) rather than nationality or ethnicity (Ataman 2003; see also Sakallioglu 1998: 81). Thus, adherents to this approach consider Islamic emphasis on the unity of God and the unity of ummah as incompatible with particularistic movements (e.g. ethnonationalist claims). Therefore, they believe that the promotion of an Islamic consciousness and values would weaken the role of ethnicity in self-identification and as a result restrain ethnonationalist and separatist tendencies. For instance, Yavuz states that 'the Islamic layer of identity could be useful in terms of containing ethnic tensions and finding a peaceful solution' (Yavuz 1998: 12).

The leadership of the ruling conservative Justice and Development Party (Adalet ve Kalkinma Partisi [AKP]) also emphasises Islamic unity and brotherhood (see also Aktürk 2011: 151; Sarigil and Fazlioglu 2013, 2014). The AKP leadership views Islam as a shared value, and thus a unifying bond or bridge between the Kurds and Turks. It is believed that Islam provides a supradentity, transcending tribal, ethnic and national identities; thus, it might be expected that emphasising and promoting Islam and Islamic values among Kurds would limit or curb Kurdish support for ethnonationalism and separatism. The next hypothesis to be tested is as follows:

\section{$\mathrm{H}_{2}$ : Religious Kurds are less likely to support separation.}

The following section presents the research design and empirical findings.

\section{Data and measurement}

To analyse the possible impact of grievance-related factors (i.e. the perception of discrimination and socio-economic differences) and of religiosity on popular support for autonomy and secession, we use an original and comprehensive public opinion survey data. One of the authors took part in the research team that developed the survey, which was administered by $A \& G$, a professional public opinion research company based in Istanbul. Before implementing the survey, we conducted and participated in pilots in Istanbul, Ankara, Malatya, Mersin and Diyarbakir provinces. After the pilots, we invited all regional heads of $A \& G$ in Ankara to attend a half-day workshop to familiarise them with the research project and the questionnaire. Because the questionnaire included sensitive topics (e.g. one's attitude towards autonomy 
and secession), some participants might have been reluctant to answer certain questions or might not have wished to reveal their true preferences (i.e. social desirability bias). One of our conclusions from the pilots was that Kurdish participants appeared more comfortable and responsive when they were interviewed by a Kurdish-speaking female interviewer. Thus, in both surveys, we used female Kurdish interviewers in regions dominated by Kurds. Outside of those regions, we usually used Turkish-language questionnaire. The first survey was implemented through face-to-face interviews with 6,516 respondents, aged 18 and above, from seven regions, 48 provinces and 369 districts and villages. In 2013, we repeated the same survey with slight modifications. The second survey involved face-to-face interviews with 7,103 participants from seven regions, 50 provinces and 398 districts and villages. ${ }^{10}$ In both surveys, respondents were selected using a multi-stage, stratified cluster sampling procedure. Age and gender quotas were also applied.

The statistical analyses below were conducted with the data provided by the Kurdish sub-sample. There are multiple ways of determining ethnic origin. A common strategy is to use mother language as an indicator. Another strategy is to rely on respondents' reports of their ethnic origin or identity. In order to have a robustness check, we utilised both. Our descriptive analyses using these two different indicators, however, did not produce very different results. In addition, these two indicators of Kurdishness do not produce much difference in terms of mass support for autonomy and secession. Thus, to save space, we only present the results based on participants' self-definition as an indicator of Kurdishness.

In 2011, fourteen per cent of respondents identified themselves as ethnic Kurds; in 2013, 17.5 per cent of respondents claimed to be Kurdish. Why this difference? We think that this slight increase is not due to any systematic sampling error because we do not see this much change in the survey's other ethnic categories. We believe that the increase is due to the relatively more open political environment with respect to Kurdish issue that emerged in early 2013. In late 2012, the government launched a new initiative to resolve the PKK violence. Through Turkey's national intelligence service (Milli Ístihbarat Teskilati), the government initiated direct talks with Abdullah Ocalan, the imprisoned PKK leader. At the end of these talks (in March 2013), Ocalan called for the end of the armed struggle. Three days after Ocalan's call, the PKK leadership in Northern Iraq declared a ceasefire and announced its decision to withdraw its militants from Turkey. The government's initiation of negotiations with the PKK leadership and the PKK's decision to cease the fighting created new optimism in the country. This new political atmosphere seems to have encouraged Turkey's Kurds to be more outspoken about their ethnic identity and demands, which is positive for data quality.

The main dependent variable in this study is support for secession or separation among the members of an ethnic group (i.e. Kurds). In one definition, secession refers to 'a kind of collective action, whereby a group (whether officially recognized as a legitimate political subunit or not) attempts to 
become independent from the state that presently claims jurisdiction over it and, in doing so, seeks to remove part of the territory from the existing state' (Buchanan 1991: 75). Another definition states that secession is 'the formal withdrawal from an established, internationally recognized state by a constituent unit to create a new sovereign state' (Bartkus 2011: 2368). Thus, secession or separation refers to political disintegration, the partition of the original state and territorial dismemberment. In this study, we examine the determinants of support for secession among the members of an ethnic group, the Kurds in Turkey. We are also interested in mass support for autonomy. As a political arrangement short of secession, autonomy refers to a kind of self-rule or special status within existing borders. It involves arrangements such as decentralisation and devolution of power in the political, economic or social spheres rather than partition or territorial dismemberment.

With respect to the measurement of popular support for secession, some studies use voting support for secessionist political parties in elections as an indicator of secessionist attitudes (see Sorens 2004, 2005). We, however, think that this indicator is not ideal. Individuals might vote for a separatist ethnic party for other reasons, so a vote for that party may not necessarily reflect a separatist attitude. It is also possible that ethnic parties might give up separatist demands and instead advocate greater autonomy in political, economic or social spheres. In other words, ethnic demands might shift back and forth between autonomy and separation (e.g. see Treisman 1997: 224). ${ }^{11}$ Thus, compared with voting for ethnic separatist parties, individuals' opinions and attitudes toward the idea of separation or autonomy would provide a more direct and precise measurement of mass support for secession. Therefore, in this study, we use participants' responses to the following survey items as indicators of mass support for autonomy and secession: 'Do you support an autonomous administration or federation for Kurds (i.e. self-governance of Kurds inside Turkey)?', and 'Should Kurds set up a new, independent state, separating from Turkey?' 12 Those who favour autonomy or secession are coded as ' 1 ' and other answers as ' 0 '.

Regarding independent variables, we used income and education levels as indicators of socio-economic status. It is a rather challenging task to quantify discrimination, but in this study, we are particularly interested in how the 'perceptions' of state discrimination influence attitudes to separation. Thus, utilising the responses to the following question would be appropriate for our purpose: 'In your opinion, do you think the state discriminates against Kurds? ${ }^{13}$

Another main independent variable is religiosity. We are aware that it is also quite difficult to measure religiosity. In the 2011 survey, the respondents were asked whether they perform prayers five times a day and whether they fast each day of Ramadan every year. Due to the salience of religiosity in public debate in Turkey, we also asked whether headscarves should be allowed in schools, including primary and high schools and whether female civil servants and public employees such as judges, prosecutors and teachers should be 
allowed to wear headscarves during work time. Then, we conducted factor analysis to see whether these variables have high loadings on the same religious commitment factor or not, based on our suspicion that each measures a different dimension of religiosity. We find that the first two and the last two questions measure different dimensions of religiosity. We then created an index from these survey items, calling the first one 'religious practice' and the second one 'religious attitude' (see Table A1). In the second survey, to measure religiosity more precisely, we added new items, such as questions related to belief in God and an afterlife and attitude towards financial interest and Sharia [Islamic law]. Similar to the first survey, we also conducted factor analysis, which generated two additive indices, capturing two different dimensions of religiosity: a faith dimension vs. an attitudinal-practical dimension (see Table A1).

While testing the above hypotheses, we also control for the possible impact of several other potentially influential variables such as partisanship, ideology, residence (rural-urban), region (southeast), unemployment, religious sect, gender and age (see Table A2 for descriptive statistics). Because the dependent variables are categorical, we use binary logistic regression with robust standard errors. Table 1 below depicts the logit analyses of Kurdish popular support for autonomy and separation.

\section{Results}

Table 1 presents the empirical results of the analysis of the determinants of popular support for autonomy and secession among Turkey's Kurds. The discrimination aspect of the grievance approach finds strong support in our analyses. One of the most robust and consistent findings across the models is that Kurds with a perception of state discrimination against them are more likely to be supportive of both autonomy and separation. One might, however, claim that we should be cautious with this result because there might be an endogeneity problem here due to a reciprocal causation. That is, Kurds, who might be demanding secession due to any other reason, might legitimise their secessionist impulse by claiming that the state discriminates against them. This would be a fair claim to make. However, due to lack of an appropriate instrumental variable, we were unable to apply instrumental variable technique to address this problem. Although we acknowledge this limitation, we should add that several historical accounts of the evolution of Turkey's Kurdish issue have suggested that Kurdish ethnonationalist movement in Turkey has emerged as a reaction against the state's denial and suppression of Kurdish ethnic identity and rights (e.g. see Barkey and Fuller 1998; Entessar 1992; Gunter 1990, 1997; Jwaideh 2006; Kirisci and Winrow 1997; Lundgren 2007; McDowall 1996; Romano 2006; Yeğen 2007). In brief, we believe that perception of discrimination seems to promote a secessionist impulse among Turkey's Kurds. However, given the possibility of reverse causation, there is a need for further research on this important issue. 


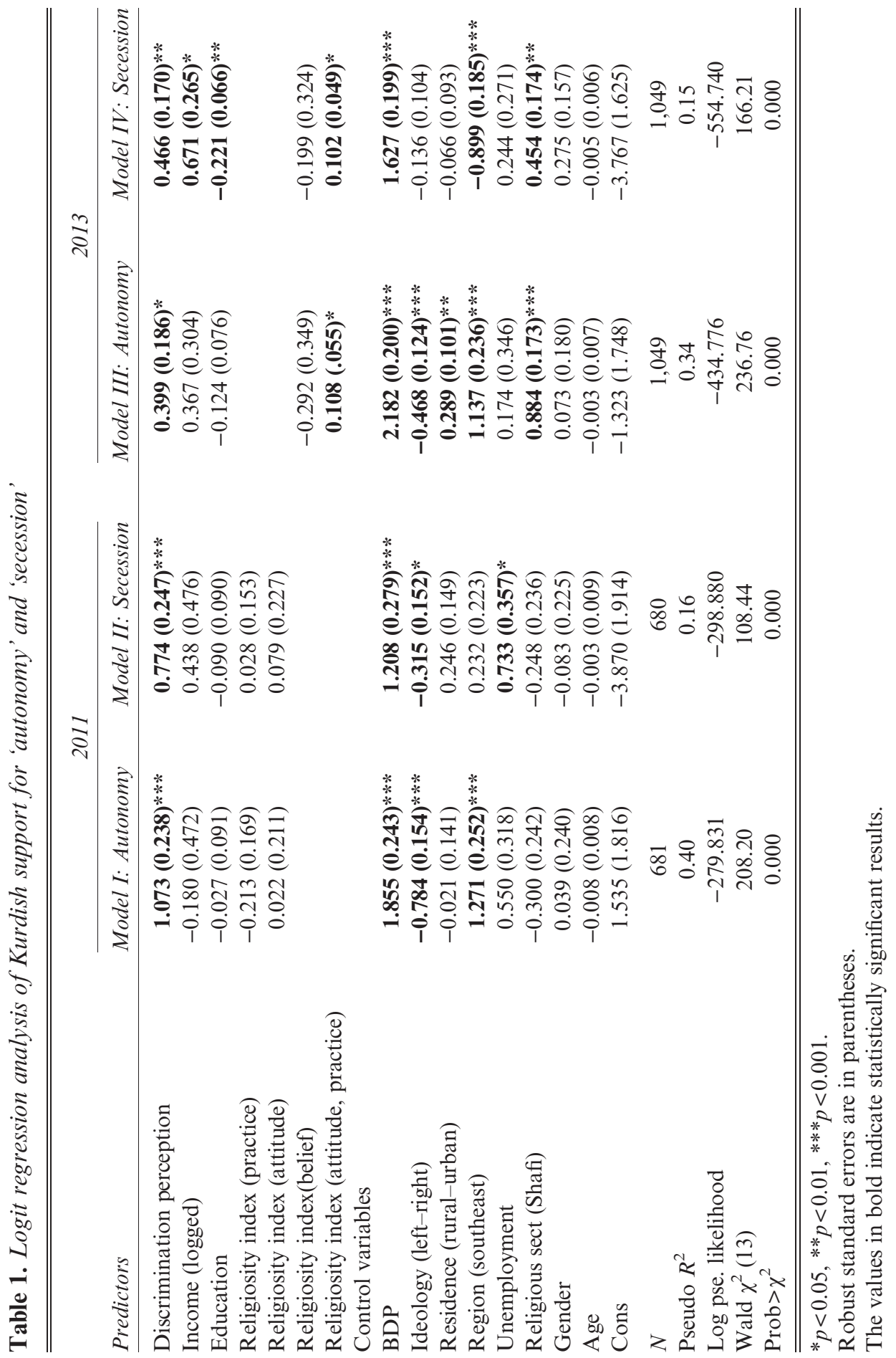


Regarding the impact of socio-economic status, as most of the models in Table 1 show, income and education do not have a statistically significant impact on secessionist attitudes. Only in Model IV (i.e. the secession model for 2013) do these variables seem to have some effect. However, rather than reducing separatist tendencies, increases in income increase the likelihood of support for secession. The only supporting evidence for the modernisation approach is that Kurds with a high level of education seem to be less likely to support secession. However, overall, these findings suggest that socio-economic status does not really matter, or at least it does not have a consistent impact on separatist dispositions among Kurds. This finding is similar to the conclusion reached by Saideman and Ayres (2000), who, in their cross-national analyses, also find no supporting evidence for the impact of economic differentials. Thus, the statistical analyses do not provide much support for the modernisation theory. One implication of this finding is that socio-economic progress or development among Kurds may not necessarily reduce support for autonomy or secession.

Religiosity has no statistically significant impact on support for autonomy and secession in the first two models. It is, however, interesting that the attitudinal and practical aspects of religiosity increase the likelihood of Kurdish support for secession in 2013. These findings directly challenge the assumptions of the pro-Islamic approach and imply that the promotion of Islam and Islamic values among Kurds would not really suppress Kurdish support for autonomy or secession.

Finally, among the control variables, we see that political factors do matter. Voters for the pro-Kurdish BDP are more likely to be supportive of autonomy and secession, which is another consistent finding across the models and time periods. ${ }^{14}$ This result is similar to Clarke et al.'s (2004) observation that when the members of an ethnic group face fundamental political issues, that involve both high uncertainty (due to limited or conflicting information) and high stakes (e.g. a decision about secession), they use partisan attachments and party identification as one of heuristic devices in their decision making. Thus, as the authors stress, political parties and elites play cue-giving roles; their discourses and attitude towards autonomy and secession constitute a focal point for the members of that ethnic community. Our findings suggest that the same dynamics are at work in Kurdish support for autonomy and secession.

With respect to the impact of ideology, left-oriented individuals are more likely to support autonomy and secession. Why is that so? In the Turkish context, although Turkish nationalism is associated with the right, the Kurdish nationalist movement (both its peaceful and violent forms) is rooted in the leftist movement. It is well-known that the PKK emerged out of the revolutionary left in Turkey in the late 1970s with a goal of establishing a united Kurdistan based on Marxist-Leninist principles (see also Criss 1995; Jongerden and Akkaya 2011; Ozcan 1999; Taspinar 2005; Yavuz 2001). By the early 1990s, however, the PKK had distanced itself from such ideas 
but did not (and does not) reject leftist inclinations altogether. The above result might be interpreted as a result of the leftist legacy of the Kurdish movement.

We also see a regional effect on the secessionist impulse. In 2011, Kurds from the southeast were more likely to support autonomy. This result is probably because the concentration of the Kurdish population and PKK activities in the southeast, also known as the Kurds' ethnic homeland, seems to have produced a stronger ethnic consciousness and greater solidarity among Kurds in that region. As indicated above, half of all Kurds worldwide live in Turkey, and most are concentrated in the southeast (see also Brown 1995: 117; Mutlu 1996). The ethnonationalist, separatist PKK is also highly organised and active in the region (Kibris 2011). Thus, the combination of these two factors appears to have empowered support for regional autonomy among Kurds residing there.

It is striking, however, that although relatively higher support for autonomy among Kurds in the southeast persists in 2013, Kurds in that region are now less likely to support secession. How is that possible? We think that one possible reason for this surprising and sudden change is the call by imprisoned PKK leader Abdullah Ocalan in the spring of 2013. On March 21, Ocalan's message from the prison on Imrali Island was shared by the BDP leadership with around one million Kurds, gathered in Diyarbakir Square to celebrate Nowruz (New Day, the New Year). ${ }^{15}$ With this message, Ocalan clearly denounced armed struggle and secession and instead asked for Kurds' support for the unity and peaceful coexistence of Turks and Kurds under democratic confederation. This historic call seems to have had the greatest impact among Kurds in the southeast. For instance, although support for secession increased almost thirteen per cent in other regions by 2013 (from 19.3 to 32 per cent), it actually declined by one per cent in the Kurdish southeast (from thirty-three to thirty-two per cent). This situation also proves that Kurdish ethnopolitical elites have a relatively higher degree of influence over Kurds in the southeast. This outcome provides further supporting evidence for the argument that ethnopolitical leaders often become principal cue givers for the members of an ethnic group (see Clarke et al. 2004).

Another notable finding is that sectarian differences (i.e. the Hanefi-Shafi division) emerge as a determining factor in Kurdish secessionism. Descriptive analyses indicate that the vast majority of Kurds in Turkey (around ninety per cent) follows Sunni Islam, which recognises four schools of law (figh): Hanefi, Shafi, Maliki and Hanbali. Among Sunni Kurds, around seventy per cent subscribe to Shafi teachings, while thirty per cent practise the Hanefi understanding. ${ }^{16}$ Model IV in Table 1 indicates that unlike Hanefi Kurds, Shafi Kurds are becoming more supportive of autonomy and secession. In other words, ethnonationalist orientations are becoming stronger among Shafi Kurds. This intriguing finding suggests that further research on the sectarian division among Sunni Kurds would be worthwhile. 
a) Autonomy

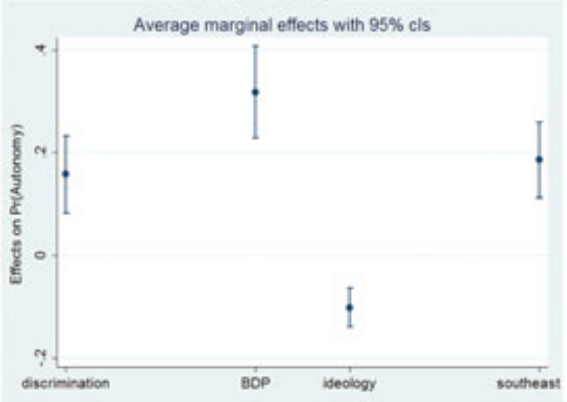

b) Secession

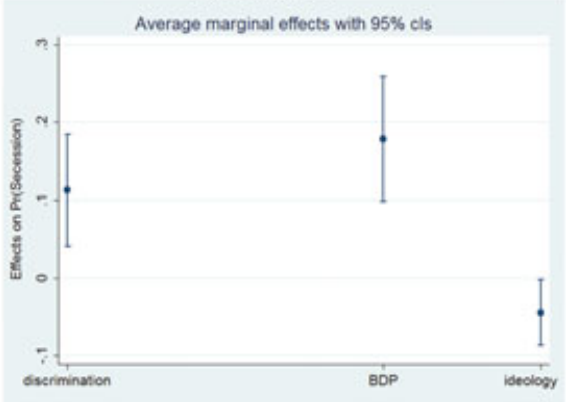

Figure 2. Average marginal effects for autonomy and secession models (2011).

\section{Marginal effects}

We also calculated the marginal effects of the key significant variables in each model. First, we present the average marginal effects for the models based on the 2011 data. For the autonomy model, Figure 2a displays the average marginal effects of perceptions of discrimination, voting for the BDP, ideology and region. It indicates that on average, the probability of supporting autonomy for those who perceive the existence of state discrimination is sixteen per cent higher than for those who do not perceive such discrimination. As for political factors, on average, the probability of support for autonomy is thirty-two per cent higher among BDP voters compared with voters for other parties. With respect to ideology, moving from the left to the right of the political spectrum decreases the predicted probability of supporting autonomy by ten per cent. Regarding the marginal effect of region, the probability of support for autonomy is eighteen per cent higher for an individual living in the southeast. Figure $2 b$, which provides the average marginal effects of discrimination, voting for the BDP and ideology for the secession model, presents a similar pattern with different magnitudes.

Figure 3 presents the average marginal effects of models' key variables using the 2013 data. Figure 3a shows that partisanship (voting for the BDP), region (being from the southeast) and religious sect (being Shafi) have relatively higher marginal effects on support for autonomy. Regarding secession, Figure $3 \mathrm{~b}$ displays that partisanship also has the largest impact on support for secession. However, region's marginal effect turns out to be negative: Kurds in the southeast are fifteen per cent less likely to support secession as of 2013. As suggested, this shift is probably due to the greater impact of Ocalan's message on Kurds living in the southeast.

\section{Conclusions and implications}

In conclusion, one of the most consistent empirical findings is that discrimination-based grievance appears to have positive impact on the secessionist 
a) Autonomy

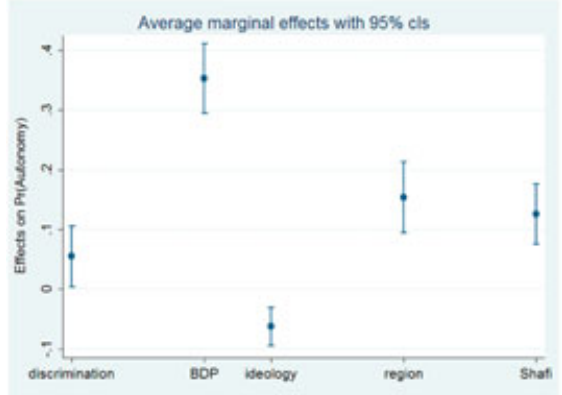

b) Secession

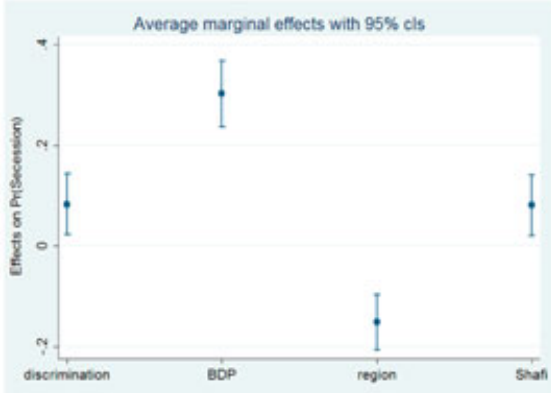

Figure 3. Average marginal effects for autonomy and secession models (2013).

attitudes: Indeed, Kurds who perceive that the state does not treat them fairly are more likely to demand their autonomy or secession. This finding provides support for the arguments that political grievances are one of the most important promoters of ethnic conflicts, which also support the findings of Regan and Norton (2005) and Walter (2006). Thus, grievance theory should be taken seriously in studies of Kurdish separatism. However, because socio-economic factors appear to have weak effect on support for secessionism, it is not reasonable to expect that modernisation processes would reduce secessionist aspirations among Kurds.

As for the religiosity approach, our findings differ from Hayes and McAllister (2001), who find that church attendance tends to depress support for paramilitary violence in Northern Ireland. Our results also contrasts with those of Zaidise et al. (2007), who draw attention to the similar depressing impact of religiosity in the case of Israel. This result implies that promoting religious ideas such as the 'Islamic brotherhood' and 'Muslim unity' among Kurds as an antidote to Kurdish ethnonationalism or secessionism is not really a realistic strategy (see also Gurses 2015; Sarigil and Fazlioglu 2013, 2014). Another major finding is that, contrary to much of the literature, ideological factors (e.g. a left-right division, electoral support for an ethnic political party) still matter in secessionism.

If a perception of discrimination promotes secession, what are the implications for conflict resolution in Turkey? In the last decade, we have seen a major change in the state's attitude towards the Kurdish issue. After the European Union (EU) accepted Turkey as a candidate country for membership in 1999, Turkey initiated a comprehensive reform process to meet EU requirements, which also included changes in state's approach to the Kurdish issue. For example, since the early 2000s, Turkish governments have legalised publishing and broadcasting in Kurdish and learning the Kurdish language. They have also permitted parents to choose Kurdish names for their children, allowed political party campaigns in Kurdish, opened Institutes of Kurdology at some public universities, introduced elective Kurdish courses 
for secondary-level public schools, allowed defence in one's mother language during court trials; restored some Kurdish place names, removed the (Turkish) nationalist oath recited by students at schools and allowed education in one's mother language in private schools. Given that Turkey denied even the existence of a distinct Kurdish ethnic identity until the early 1990s, such reforms constitute major changes. However, as shown above, at least half of Turkey's Kurds still think that the state discriminates against them. Therefore, Turkish governments should take further steps to limit discrimination perception among Kurds. ${ }^{17}$

Finally, we should take into account the recent developments in the region, which are likely to affect the relationship between discrimination-based grievance and separatist beliefs among Turkey's Kurds. One relevant development is that Kurds in Iraq and Syria have gained significant political and economic powers in the last decades. In the aftermath of the Gulf War (1990-91), a de facto Kurdish state was established in Northern Iraq (Freij 1998; Gunter 1993, 2004; Lundgren 2007; Rafaat 2007). ${ }^{18}$ In addition, Syrian Kurds also gained a kind of autonomy, following the withdrawal of Syrian army from Kurdish areas (northern and north-eastern Syria, also known as Rojavaye) in 2012. The Turkish state fears that such regional developments might encourage or incite a separatist disposition among Turkey's Kurds (such an occurrence is also called the demonstration effect) (Brown 1995; Lundgren 2007). Such fears are not groundless as existing studies provide some empirical support for the 'demonstration effect'. For instance, Saideman and Ayres (2000) show that secessionism is contagious in the sense that if there is active separatism among a group's kin elsewhere, the likelihood of the group as a whole desiring separation increases (see also Gurr et al. 1993; Hale 2000; Sorens 2005). Thus, given such regional developments and the contagious nature of secessionism, it becomes even more vital that the Turkish state should initiate further reforms in political, economic, social and cultural realms to curb Kurdish perceptions of discrimination and so secure their loyalty.

\section{Acknowledgements}

An earlier version of this article was presented at the 71st Annual Midwest Political Science Association (MPSA) Conference, 11-14 April 2013, Chicago, USA. The authors would like to thank Sabri Ciftci, Arzu Kibris, Brian D. Shoup, Gunes Murat Tezcur, reviewers and journal editors for their valuable comments and suggestions on earlier versions of this study.

\section{Notes}

1 Although the origin of the Kurds is still disputed, there is general consensus that Kurds are the descendants of Medes, an Indo-European tribe (see Entessar 1992: 3; White 2000: 14). Regarding the linguistic and religious characteristics, the Kurdish language is regarded as a member of the 
Iranian languages, which stem from the Indo-European family (Entessar 1992: 4; Jwaideh 2006: 11; White 2000: 16). Like their Turkish compatriots, most Kurds (ninety per cent) subscribe to the Sunni Muslim faith.

2 The estimated number of deaths due to the conflict between 1984 and 2012 is around 40,000. However, the ceasefire and the peace process, which was initiated in 2013, collapsed in summer 2015. Both domestic and regional developments played a role in this outcome. For instance, the ruling Justice and Development Party (Adalet ve Kalkınma Partisi [AKP]) was highly disturbed by the Kurdish gains in Northern Syria (e.g. the formation of de facto autonomous cantons in the region and successful Kobani resistance) and the impressive electoral performance of proKurdish People's Democratic Party (Halklarin Demokratik Partisi, HDP) in the 2015 general elections, which made singly party government impossible and complicated AKP's plans for installing a presidential system. All these developments weakened AKP's commitment to the peace process. As a response, the PKK resumed armed attacks against security forces in the aftermath of the general elections.

3 The vast majority of ethnic Turks (around ninety-five per cent), however, is against the establishment of an independent Kurdish state.

4 In 2014, the BDP was replaced by the HDP. During its first electoral competition (i.e. the June 2015 general elections), the HDP received thirteen per cent of national votes and secured 80 seats in the parliament, an unprecedented electoral success in the history of Kurdish ethnopolitics.

5 For one estimation, the number of extra-judicial killings between 1990 and 2011 is 1901 (see Milliyet, 25 January 2012. http://www.milliyet.com.tr/21-yilda-1901-faili-mechul/gundem/ gundemdetay/26.01.2012/1493812/default.htm. Accessed on 4 March 2015).

6 For more discussion on the evolution of state attitudes towards Kurds, see Gunter 1990 and 1997, Entessar 1992, McDowall 1996, Kirisci and Winrow 1997, Barkey and Fuller 1998, Jwaideh 2006, Romano 2006, Lundgren 2007, and Yeğen 2007 and Aktürk 2011.

7 However, only nine per cent of ethnic Turks think that the state discriminates against Kurds.

8 See also Roeder 1991, Emizet and Hesli 1995, Treisman 1997 and Sorens 2005.

9 See also Sorens 2004 and Sambanis and Milanovic 2011.

10 The following provinces are included in the sample: Adana, Adiyaman, Afyon, Agr1, Amasya, Ankara, Antalya, Aydin, Balikesir, Batman, Bingol, Burdur, Bursa, Cankırı, Corum, Denizli, Diyarbakir, Elazıg, Edirne, Erzurum, Eskisehir, Gaziantep, Giresun, Hatay, Isparta, Icel, Istanbul, Izmir, Karabük, Kayseri, Kırklareli, Kocaeli, Konya, Malatya, Manisa, Maras, Mardin, Nigde, Ordu, Osmaniye, Rize, Sakarya, Samsun, Sivas, Tunceli, Trabzon, Sanlıurfa, Usak, Van and Zonguldak.

11 The Kurdish movement constitutes a good example of such shifts. The PKK, which emerged as a separatist organisation in the mid-1970s, distanced itself from the idea of separation in its later years (see also Criss 1995; Kibris 2011). Especially since the early 2000s, the PKK and pro-Kurdish legal political parties have been advocating greater autonomy for the Kurds within a federal structure.

12 For a similar measurement strategy, see Hagendoorn, Poppe and Minescu 2008.

13 In this study, we are more interested in the possible impact of 'perceptions of discrimination' on secessionist attitudes. In future research, we intend to investigate whether the type of discrimination (economic, social or political) creates any difference.

14 In terms of voting preferences, the majority of Kurdish respondents declare that they prefer pro-Kurdish BDP. In terms of voting preferences across religious sect, Shafi Kurds are more likely to prefer the BDP, while Hanefi Kurds tend to vote for the AKP.

15 Diyarbakir is the largest city in the southeast, mostly inhabited by Kurds. Kurdish ethnonationalists consider the city as Kurdish capital.

16 The most popular schools within Sunni Islam in Turkey are the Hanefi and Shafi teachings, which are quite similar in terms of faith. Their differences seem to be more related to rituals or practices. For instance, Shafis perform morning prayer earlier and they hold their hands in a different position during prayer. They also have different rules for what disturbs ritual purity (see Bruinessen 2000: 15). Although the majority of Turkey's Sunni Kurds follow the Shafi understanding, the vast majority of Turks (around ninety per cent) subscribes to the Hanefi school, 
which was the official school of the Ottoman Empire. The Turkish state is still in favour of Hanefi school.

17 Some of major Kurdish demands are decentralisation, a democratic constitution recognising Kurdish identity, the removal of ten per cent electoral threshold, public education in mother language and amnesty for PKK members.

18 The Kurdistan Regional Government, which rules the Kurdish region in Northern Iraq, has its own parliament, army, flag and national anthem.

\section{References}

Aktürk, Ş. 2011. 'Regimes of ethnicity: comparative analysis of Germany, the Soviet Union/PostSoviet Russia, and Turkey', World Politics 63: 115-64.

Ataman, M. 2003. 'Islamic Perspective on ethnicity and nationalism: diversity or uniformity?, Journal of Muslim Minority Affairs / Institute of Muslim Minority Affairs 23: 89-102.

Barkey, H. J. and Fuller, G. E. 1998. Turkey's Kurdish Question. New York: Rowman and Littlefield Publishers.

Bartkus, V. O. 2011. 'Secession' in B. Badie et al. (eds.), International Encyclopedia of Political Science. Thousand Oaks, CA: Sage Publications.

Brown, J. 1995. 'The Turkish imbroglio: its Kurds', The Annals of the American Academy of Political and Social Science 54: 116-29.

Bruinessen, M. V. 2000. Mullahs, Sufis and Heretics: The Role of Religion in Kurdish Society: Collected Articles. Istanbul: Isis Press.

Buchanan, A. E. 1991. Secession: The Morality of Political Divorce from Fort Sumter to Lithuania and Quebec. Boulder, CO: Westview Press.

Clarke, H. D. et al. 2004. 'Referendum voting as political choice: the case of Quebec', British Journal of Political Science 34: 345-55.

Collier, P. et al. 2004. 'On the duration of civil war', Journal of Peace Research 41: 253-73.

Cornell, S. E. 2001. 'The Kurdish question in Turkish politics', Orbis 45: 31-46.

Criss, N. B. 1995. 'The nature of PKK terrorism in Turkey', Studies in Conflict and Terrorism 18: $17-37$.

Cuneo, C. J. and Curtis, J. E. 1974. 'Quebec separatism: an analysis of determinants within socialclass levels', Canadian Review of Sociology = Revue Canadienne de Sociologie 11: 1-29.

Emizet, K. N. and Hesli, V. L. 1995. 'The disposition to secede an analysis of the Soviet case', Comparative Political Studies 27: 493-536.

Entessar, N. 1992. Kurdish Ethnonationalism. Boulder and London: Lynn Rienner Publishers Boulder.

Ergil, D. 2000. 'The Kurdish question in Turkey', Journal of Democracy 11: 122-35.

Fearon, J. D. and Laitin, D. D. 2003. 'Ethnicity, insurgency, and civil war', American Political Science Review 97: 75-90.

Fox, J. 2004. 'Religion and state failure: an examination of the extent and magnitude of religious conflict from 1950 to 1996', International Political Science Review 25: 55-76.

Freij, H. Y. 1998. 'Alliance patterns of a secessionist movement: the Kurdish Nationalist Movement in Iraq', Journal of Muslim Minority Affairs / Institute of Muslim Minority Affairs 18: 19-37.

Gellner, E. 1983. Nations and Nationalism. Ithaca: Cornell University Press.

Gottlieb, G. 1994. 'Nations without states', Foreign Affairs 73: 100-12.

Gunter, M. M. 1990. The Kurds in Turkey: A Political Dilemma. Boulder: Westview Press.

Gunter, M. M. 1993. 'A De Facto Kurdish State in Northern Iraq', Third World Quarterly 14: 295-319.

Gunter, M. M. 1997. The Kurds and the Future of Turkey. New York: Sn. Martin's Press.

Gunter, M. M. 2004. 'The Kurdish question in perspective', World Affairs 166: 197-205.

Gurr, T. R. 1970. Why Men Rebel. Princeton: Princeton University Press.

(C) The author(s) 2016. Nations and Nationalism (C) ASEN/John Wiley \& Sons Ltd 2016 
Gurr, T. R. and Harff, B. 1994. Ethnic Conflict in World Politics. Boulder, CO: Westview Press.

Gurr, T. R. and Moore, W. H. 1997. 'Ethnopolitical rebellion: a cross-sectional analysis of the 1980s with risk assessments for the 1990s', American Journal of Political Science 41: 1079-103.

Gurr, T. R. et al. 1993. Minorities at Risk: A Global View of Ethnopolitical Conflicts. Washington, DC: US Institute of Peace Press.

Gurses, M. 2015. 'Is Islam a cure for ethnic conflict? Evidence from Turkey', Politics and Religion 8: $135-54$.

Hagendoorn, L. et al. 2008. 'Support for separatism in ethnic Republics of the Russian Federation', Europe-Asia Studies 60: 353-73.

Hale, H. E. 2000. 'The parade of sovereignties: testing theories of secession in the Soviet setting', British Journal of Political Science 30: 31-56.

Hayes, B. C. and McAllister, I. 2001. 'Sowing dragon's teeth: public support for political violence and paramilitarism in Northern Ireland', Political Studies 49: 901-22.

Hechter, M. 1975. Internal Colonialism: The Celtic fringe in British National Development, 15361966. Berkeley: Univ of California Press.

Heraclides, A. 1990. 'Secessionist minorities and external involvement', International Organization 44: 341-78.

Horowitz, D. L. 1981. 'Patterns of ethnic separatism', Comparative Studies in Society and History 23: $165-95$.

Horowitz, D. L. 1985. Ethnic Groups in Conflict. Berkeley: University of California Press.

Icduygu, A. et al. 1999. 'The ethnic question in an environment of insecurity: the Kurds in Turkey', Ethnic and Racial Studies 22: 991-1010.

Jongerden, J. and Akkaya, A. H. 2011. 'Born from the left: the making of the PKK' in M. Casier and J. Jongerden (eds.), Nationalism and Politics in Turkey: Political Islam, Kemalism and the Kurdish Issue. New York: Routledge.

Jwaideh, W. 2006. The Kurdish National Movement: Its Origins and Development. New York: Syracuse University Press.

Kibris, A. 2011. 'Funerals and elections: the effects of terrorism on voting behavior in Turkey', The Journal of Conflict Resolution 55: 220-47.

Kirisci, K. and Winrow, G. M. 1997. The Kurdish Question and Turkey: An Example of a TransState Ethnic Conflict. Portland, Oregon: Frank Cass.

Loizides, N. G. 2010. 'State ideology and the Kurds in Turkey', Middle Eastern Studies 46: $513-27$.

Lundgren, A. 2007. The Unwelcome Neighbour: Turkey's Kurdish Policy. New York: IB Tauris.

McDowall, D. 1996. A Modern History of the Kurds. London: IB Tauris.

Mutlu, S. 1996. 'Ethnic Kurds in Turkey: a demographic study', International Journal of Middle East Studies 28: 517-41.

Mutlu, S. 2001. 'Economic bases of ethnic separatism in Turkey: an evaluation of claims and counterclaims', Middle Eastern Studies 37: 101-35.

O'Gara, M. 2001. 'Inequality and political violence in a divided society: charismatic movements in Northern Ireland', Civil Wars 4: 79-98.

Ozcan, N. A. 1999. PKK (Kurdistan Isci Partisi) Tarihi, Ideolojisi, Ve Yontemi. Ankara: ASAM.

Rafaat, A. 2007. 'An independent Kurdish State: achievable or merely a Kurdish dream?', The Journal of Social, Political, and Economic Studies 32: 267-304.

Regan, P. M. and Norton, D. 2005. 'Greed, grievance, and mobilization in civil wars', The Journal of Conflict Resolution 49: 319-36.

Reynal-Querol, M. 2002. 'Ethnicity, political systems, and civil wars', The Journal of Conflict Resolution 46: 29-54.

Richez, E. and Bodet, M. A. 2012. 'Fear and disappointment: explaining the persistence of support for Quebec secession', Journal of Elections, Public Opinion and Parties 22: 77-93.

Roeder, P. G. 1991. 'Soviet federalism and ethnic mobilization', World Politics 43: 196-232.

Roeder, P. G. 2003. 'Clash of civilizations and escalation of domestic ethnopolitical conflicts', Comparative Political Studies 36: 509-40. 
Romano, D. 2006. The Kurdish Nationalist Movement: Opportunity, Mobilization and Identity. Cambridge: Cambridge University Press.

Rudolph, J. R. and Thompson, R. J. 1985. 'Ethnoterritorial movements and the policy process: accommodating nationalist demands in the developed world', Comparative Politics 17: 291-311.

Rummel, R. J. 1997. 'Is collective violence correlated with social pluralism?', Journal of Peace Research 34: 163-75.

Saideman, S. M. and Ayres, R. W. 2000. 'Determining the causes of irredentism: logit analyses of minorities at risk data from the 1980s and 1990s', The Journal of Politics 62: 1126-44.

Sakallioglu, U. C. 1998. 'Kurdish Nationalism from an Islamist perspective: the discourses of Turkish Islamist writers', Journal of Muslim Minority Affairs / Institute of Muslim Minority Affairs 18: 73-89.

Sambanis, N. and Milanovic, B. 2011. 'Explaining the Demand For Sovereignty', World Bank Policy Research Working Paper Series (Vol. 5888): World Bank.

Sarigil, Z. 2010. 'Curbing Kurdish ethno-nationalism in Turkey: an empirical assessment of pro-Islamic and socio-economic approaches', Ethnic and Racial Studies 33: 533-53.

Sarigil, Z. 2012. 'Ethnic groups at 'Critical Junctures': the Laz vs. Kurds', Middle Eastern Studies 48: 269-86.

Sarigil, Z. and Fazlioglu, O. 2013. 'Religion and ethno-nationalism: Turkey's Kurdish issue', Nations and Nationalism 19: 551-71.

Sarigil, Z. and Fazlioglu, O. 2014. 'Exploring the roots and dynamics of Kurdish ethnonationalism in Turkey', Nations and Nationalism 20: 436-58.

Sorens, J. 2004. 'Globalization, secessionism, and autonomy', Electoral Studies 23, 4: 727-52.

Sorens, J. 2005. 'The cross-sectional determinants of secessionism in advanced democracies', Comparative Political Studies 38: 304-26.

Taspinar, O. 2005. Kurdish Nationalism and Political Islam in Turkey: Kemalist Identity in Transition. New York: Routledge.

Tezcür, G. M. 2009. 'Kurdish nationalism and identity in Turkey: a conceptual reinterpretation', European Journal of Turkish Studies 10: 1-5.

Tezcür, G. M. 2010. 'When democratization radicalizes: the Kurdish nationalist movement in Turkey', Journal of Peace Research 47: 775-89.

Treisman, D. S. 1997. 'Russia's "Ethnic Revival": the separatist activism of regional leaders in a postcommunist order', World Politics 49: 212-49.

Walker, I. et al. 2002. 'Relative deprivation and attribution: from grievance to action' in I. Walker and H. J. Smith (eds.), Relative Deprivation: Specification, Development, and Integration. Cambridge: Cambridge University Press.

Walter, B. F. 1997. 'The critical barrier to civil war settlement', International Organization 51: 335-64.

Walter, B. F. 2006. 'Building reputation: why governments fight some separatists but not others', American Journal of Political Science 50: 313-30.

White, P. J. 1998. 'Economic marginalization of Turkey's Kurds: the failed promise of modernization and reform', Journal of Muslim Minority Affairs / Institute of Muslim Minority Affairs 18: 139-58.

White, P. J. 2000. Primitive Rebels or Revolutionary Modernizers?: The Kurdish National Movement in Turkey. London, New York: Zed books.

Williams, C. H. (ed.). 1982. National Separatism. Cardiff: University of Wales Press.

Wood, J. R. 1981. 'Secession: a comparative analytical framework', Canadian Journal of Political Science. Revue Canadienne de Science Politique 14: 107-34.

Yavuz, M. H. 1998. 'A preamble to the Kurdish Question: the politics of Kurdish identity', Journal of Muslim Minority Affairs / Institute of Muslim Minority Affairs 18: 9-18.

Yavuz, M. H. 2001. 'Five stages of the construction of Kurdish nationalism in Turkey', Nationalism and Ethnic Politics 7: 1-24.

Yeğen, M. 1996. 'The Turkish State discourse and the exclusion of Kurdish identity', Middle Eastern Studies 32: 216-29.

(C) The author(s) 2016. Nations and Nationalism (C) ASEN/John Wiley \& Sons Ltd 2016 
Yeğen, M. 2007. 'Turkish nationalism and the Kurdish question', Ethnic and Racial Studies 30: $119-51$.

Yeğen, M. 2011. 'The Kurdish question in Turkey: denial to recognition' in M. Casier and J. Jongerden (eds.), Nationalisms and Politics in Turkey: Political Islam, Kemalism and the Kurdish Issue. New York: Routledge.

Zaidise, E. et al. 2007. 'Politics of God or politics of man? The role of religion and deprivation in predicting support for political violence in Israel', Political Studies 55: 499-521.

\section{Appendix}

Table A1. Factor analysis of religiosity

\begin{tabular}{|c|c|c|c|c|c|}
\hline \multicolumn{3}{|l|}{2011} & \multicolumn{3}{|c|}{2013} \\
\hline \multirow[b]{2}{*}{ Variables } & \multicolumn{2}{|c|}{ Factor loadings } & \multirow[b]{2}{*}{ Variables } & \multicolumn{2}{|c|}{ Factor loadings } \\
\hline & $\begin{array}{l}\text { 1: } \\
\text { Attitude }\end{array}$ & $\begin{array}{l}\text { 2: } \\
\text { Practice }\end{array}$ & & $\begin{array}{l}\text { 1: Attitude, } \\
\text { Practice }\end{array}$ & $\begin{array}{l}\text { 2: } \\
\text { Faith }\end{array}$ \\
\hline $\begin{array}{l}\text { Daily prayer } \\
\text { (five times) }\end{array}$ & 0.101 & 0.863 & $\begin{array}{l}\text { Belief in } \\
\text { afterlife }\end{array}$ & 0.134 & 0.922 \\
\hline $\begin{array}{l}\text { Fasting during } \\
\text { Ramadan }\end{array}$ & 0.198 & 0.825 & $\begin{array}{l}\text { Belief in God } \\
\text { (Allah) }\end{array}$ & 0.123 & 0.924 \\
\hline $\begin{array}{l}\text { Headscarves for } \\
\text { primary students }\end{array}$ & 0.911 & 0.169 & $\begin{array}{l}\text { Opposition to } \\
\text { financial interest }\end{array}$ & 0.611 & 0.218 \\
\hline $\begin{array}{l}\text { Headscarves for } \\
\text { public employees }\end{array}$ & 0.916 & 0.148 & $\begin{array}{l}\text { Daily prayer } \\
\text { (five times) }\end{array}$ & 0.707 & 0.60 \\
\hline \multirow[t]{5}{*}{$\%$ of variance } & 42 & 36 & $\begin{array}{l}\text { Fasting during } \\
\text { Ramadan }\end{array}$ & 0.732 & 0.178 \\
\hline & & & $\begin{array}{l}\text { Headscarves for } \\
\text { primary students }\end{array}$ & 0.793 & 0.120 \\
\hline & & & $\begin{array}{l}\text { Headscarves for } \\
\text { public employees }\end{array}$ & 0.789 & 0.121 \\
\hline & & & Support for Sharia & 0.546 & -0.009 \\
\hline & & & $\%$ of variance & 37 & 22 \\
\hline
\end{tabular}

Notes: Extraction method: Principal component analysis.

Rotation method: Varimax with Kaiser Normalisation.

Rotation converged in three iterations.

The values in bold indicate relatively higher factor loadings. 


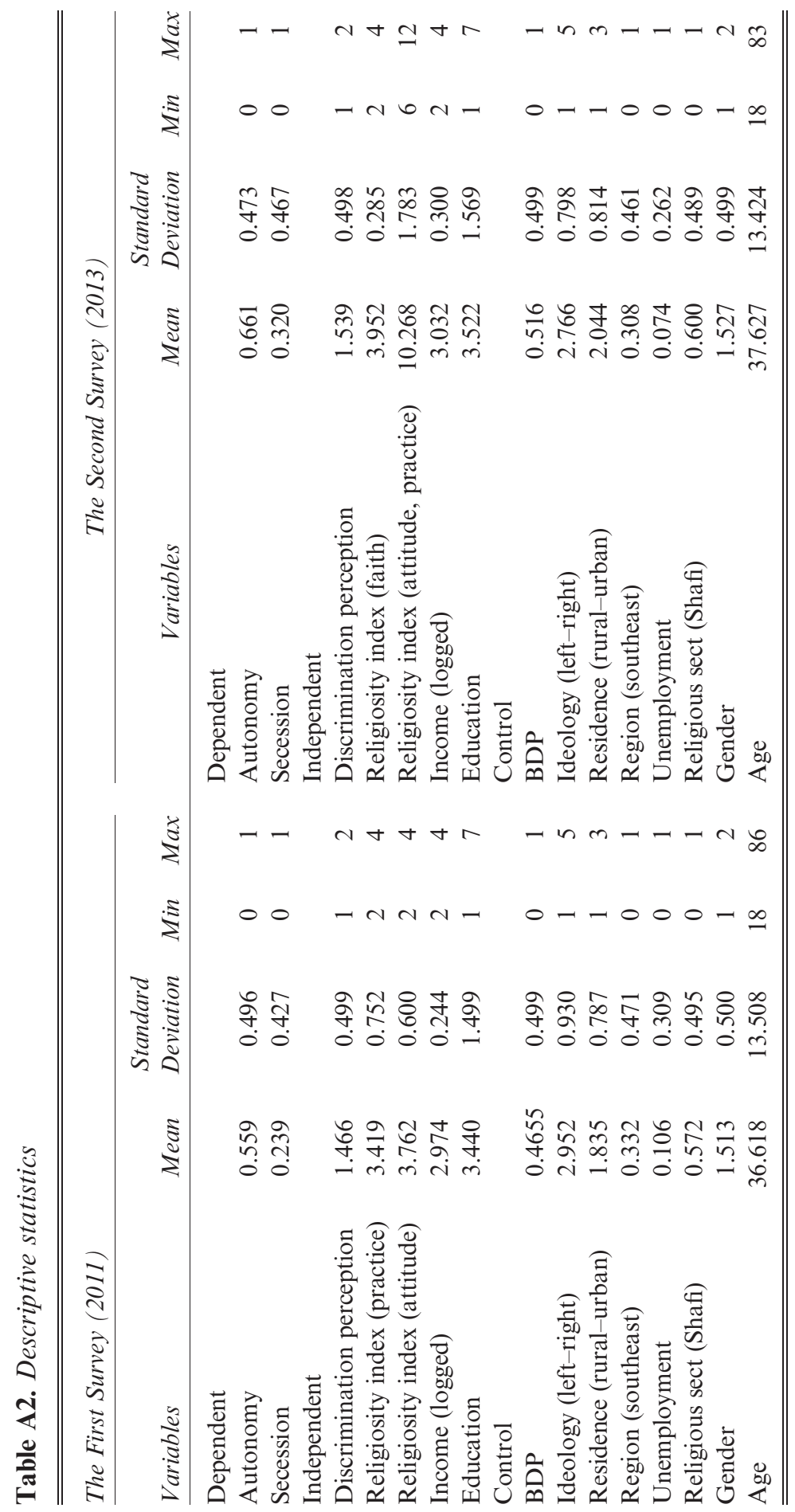

